\title{
The Circle Game: Poetry and Sustainable Enterprises
}

\author{
${ }^{1}$ Rick Edgeman, ${ }^{2}$ Kunal Yogen Sevak \\ 1,2 Management Department, Robbins College of Business \& Entrepreneurship, Fort Hays \\ State University, USA
}

\begin{abstract}
Organisational progress toward sustainable social and natural environments is essential. So too, is financial performance sufficient to support organisational investment in sustainability. Perspectives as to what organisational sustainability is, how it is pursued, and its preferred fruits have evolved in recent years to incorporate both inclusion and circularity. Regardless of the prevalent organisational perspective, the organisation will need to formulate and execute a triple top-line strategy to deliver triple bottom line performance and impacts. Interpretation of inclusion depends on whether organisational focus is internal, or is riveted on people, communities, or societies the organisation serves or hopes to impact. Herein inclusion is principally outward-looking, and hence primarily addresses marginalised individuals or groups, including individuals at the base of the pyramid. Organisations aiming to 'do well, by doing good' are called for-benefit organisations and are central to this effort and, often, are inclusive businesses. More than 'doing good', such organisations may aid disadvantaged or marginalised individuals or groups through beneficial cultural innovation and transformation. Companion to inclusivity is circularity, where businesses focus on resource recovery and redeployment. New business models aiming to direct organisations toward sustainable excellence, will incorporate inclusivity and circularity.
\end{abstract}

Keywords: Base of the pyramid, Circular economy, Cultural innovation and transformation, For-benefit organisations, Inclusive business, Triple top-line strategy

\section{Introduction}

Exceptional organisations strive for sustainable excellence across a select collection of performance domains that include leadership and governance; human ecology; economic performance; processes, systems and operations; customer-related; and innovation. Organisations that are more holistically committed will typically add social and environmental performance to this portfolio and will hence formulate strategy with a triple top-line strategic orientation that aims to deliver triple bottom line performance.

Increasingly, organisations - whether internally motivated or due to external pressures - aim to positively impact disadvantaged or marginalised individuals, communities and cultures through employment creation, products and services, or through direct engagement, often with the expectation this will lead to mutually beneficial results. Similarly, many organisations have become increasingly committed to stewardship of technical and biological nutrients (inputs) in ways that preserve and repeatedly redeploy those nutrients, a strategy referred to as circular economy, cradle-to-cradle, or zero-waste (Veleva, Bodkin and Todorova, 2017).

While prior business models have thoughtfully integrated social and environmental concerns with business ones to yield sustainable enterprise excellence models (Edgeman and Eskildsen, 2014; Edgeman, 2019a), going so far as to incorporate both resilience and robustness, it has been increasingly evident that progressive business models should also advance inclusion and circularity. Core values, guiding principles, and organisation purpose provide the initial drivers 
or inputs in such models with recommended ones discussed herein. Similarly, strategies and actions meant to advance sustainable enterprise excellence, inclusion and circularity are addressed.

Collectively, these provide the content of this manuscript, with varied perspectives of both inclusion and circularity presented, including expert ones, and analogies from poetry and prose that illustrate the presence of these notions in our everyday existence.

\section{Poetry and Principles of Inclusion}

Painted with a human face, poet and musician Joni Mitchell - a self-described 'painter derailed by circumstance' - composed a song in 1970 entitled The Circle Game that captured the notions of circularity and contra-inclusion, e.g., division and exclusion, (Mitchell, 1997). Appendix A provides the lyrics of The Circle Game.

Written as a coming-of-age tome, lyrics of The Circle Game point to multiple elements of both circularity and inclusion, in both failing and ideal forms. The circle game is a game of distinction or denial for some, recognition and inclusion for others.

We are born with the world virgin to our eyes and experience, a place of awe, wonder and opportunity to our right and peril and pain to our left, heaven above us and hell beneath. Often it is the circumstances of our birth that determine the quadrant of this bi-dichotomy we inhabit, and hence the terms of our existence.

The circumstances of those subject to peril and pain, and hell beneath are analogous to the plight of those memorialised in Rudyard Kipling's work, The Song of the Galley Slave (Kipling, 1920), an archetype of modern slaves, estimated to number about 40 million globally, or about 1-in-195 of the world's human inhabitants (Davidson, 2015, also see: https://www.worldometers.info/). See Appendix B for Kipling's work.

We enter the world as part of the human fellowship. Still we are then are excluded from its benefits and responsibilities - seen in words of The Circle Game such as "when you're older" or "take your time, it won't be long now" - that indicate a denial of opportunities and resources that remain out of reach, however tantalisingly close they may seem - not as abnegation or self-denial -due to rules and regulations, castes and colour, sects and sex, pounds and pence, birth and birthplace, sameness and difference.

The nature and management of interdependent relationships between organisations and society have long been of interest. The need for these relationships to be mutually beneficial, creating acceptable value for all relevant parties has become increasingly apparent as a means of unleashing a wave of much needed social-and-ecologically-driven innovation (Porter and Kramer, 2019), as depicted in Figure 1. This perspective has evolved from increased awareness that many organisations have profited from activities deemed drivers of social, environmental and economic challenges affecting the broader community.

Organisations committed to behaving in ways that promote broad-based and mutually beneficial performance and impacts typically do so in ways that intentionally embrace inclusivity. They do so by consciously and continuously expanding access to goods, services, and economic and social opportunities to materially or socially disadvantaged individuals, societies, and cultures. Disadvantaged is intended as sweeping in expanse, spanning individual, community, societal, or cultural levels. Commonly acknowledged among these are individuals subject to various physical, mental, or emotional challenges; communities with severely restricted access to resources such as water or energy or services such as healthcare or education; people groups historically marginalised because of the colour of their skin, who they love, what they believe, or from whence they originate; those being or having been incarcerated who - even after 'paying 
their debt to society' - are devoid of rights granted to 'ordinary citizens' and become permanently disadvantaged due to the record haunting them; and societies where children or women bear significant labour burden.

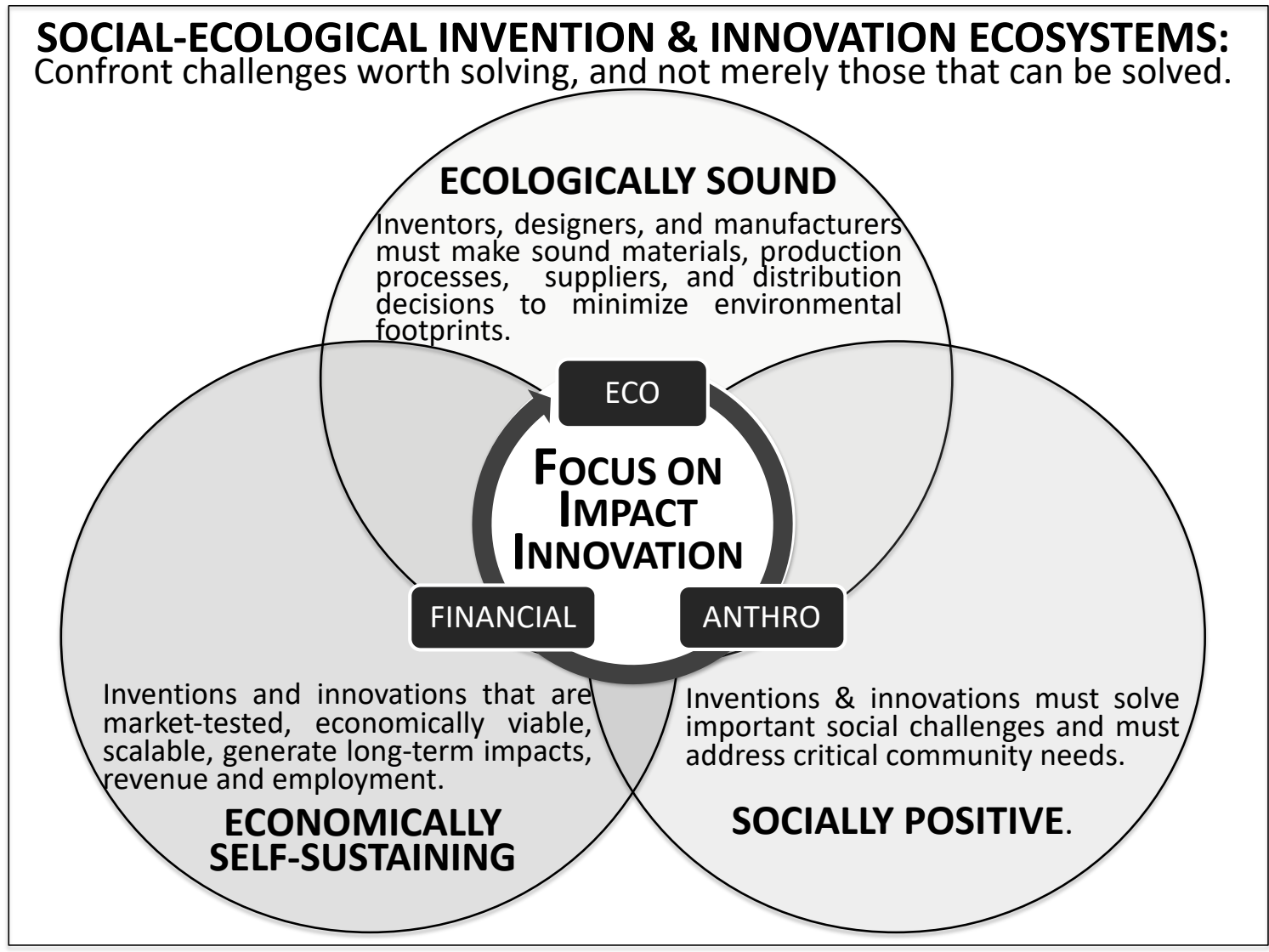

Figure 1: Social-Ecological Innovation for the Circular Economy

Source: Edgeman et al., 2018.

Victims of marginalisation are often stigmatised and subjected to feelings of alienation and inadequacy, to additional economic or social penalties and, in extreme circumstances, to increased peril of injury or death. Many such individuals are among the world's four billion people living in abject poverty at the base of the pyramid (BOP), earning no more than USD 2,000 annually (Hahn, 2012; Joncourt et al., 2019). Inclusive organisations aim to perform at an acceptable financial level while concurrently elevating human dignity by alleviating poverty, marginalization, alienation, and feelings of inadequacy through increased economic and social opportunity and participation. These align with the rise of the for-benefit sector, composed of enterprises pursuing social and environmental good in tandem with acceptable financial performance (Broadstock et al., 2019; Hiller, 2013; Reiser, 2011; Sabadoz, 2011; Sabeti, 2011). Many for-benefit organisations emphasise social-ecological invention and innovation to support this tripartite mission (Edgeman, 2019a; Olsson and Galaz, 2012; Pfitzer, Bockstette and Stamp, 2019).

Logically, the business model of an organisation claiming to value inclusion will intentionally incorporate elements cited above that are relevant to the organisation's competitive, social, and environmental contexts and will routinely seek answers to such questions as:

- What is the experience for individuals both within and external to the organisation who are in the minority or otherwise marginialised? 
- What barriers that prevent marginalised people from feeling welcome and having a sense of belonging can be identified and addressed by the organisation?

- What have we failed to realize we are doing, both as individuals and collectively, that negatively impact our new, more diverse, teams within the organisation, and in our supply chains?

Thorough incorporation of these elements will permeate the organisations guiding principles, purpose, and core values and inform organisational vision, mission and strategy, and how these are deployed and the nature of specific results and impacts the organisation esteems (Edgeman, 2019). Similarly, routinely asking and answering questions such as the above will drive deeper penetration and heighten understanding of inclusion.

\subsection{Core Values and Guiding Principles}

Examples of relevant guiding principles and core values include social and environmental justice (McIntyre-Mills, 2004; McIntyre-Mills, 2018); humility, mutual respect, applying scientific and critical thinking, thinking and acting systemically, establishing unity of purpose, and creating shared vision (Edgeman, 2018; Edgeman, 2019b); equality, broadmindedness and world at peace (Schwartz, 2007); and the ten principles of the United Nations Global Compact (Nason, 2008; Sethi and Schepers, 2014) to which approximately 14,000 organisations adhere and that are divided among four categories: environment, human rights, labour, and anti-corruption. Organisations may choose to embed these as expectations informal codes of ethical conduct (Kourula, Pisani and Kolk, 2017).

\subsection{Strategy, Mission, Vision and Purpose}

Core values and guiding principles should be deeply integrated into organisation mission, vision, strategy and purpose, general descriptions of which are provided in Table 1. While these will be organisationally specific, promotion of inclusivity to attain desired performance and impacts should be made explicit in each of purpose, mission, vision and strategy.

Table 1. Generic Descriptions of Organisational Purpose, Vision, Mission and Strategy

\begin{tabular}{|l|l|}
\hline Element & Generic Description \\
\hline Purpose & $\begin{array}{l}\text { Purpose is the unifying principle that drives everything the enterprise does. Many } \\
\text { believe that purpose cannot be fully realized and for that reason supplies stimulus for } \\
\text { change and progress. It drives force behind ongoing organisation development. }\end{array}$ \\
\hline Mission & $\begin{array}{l}\text { Mission aligns an enterprise's human ecology with shared focus. It describes the } \\
\text { both the oranisation's current business and its anticipated future business. }\end{array}$ \\
\hline Vision & $\begin{array}{l}\text { Vision provides the motivations behind and means of fulfillment for mission and } \\
\text { purpose. }\end{array}$ \\
\hline Strategy & $\begin{array}{l}\text { Strategy is a method or plan of action chosen to realize an organisation's desired } \\
\text { future. Strategic planning is the art and science of planning and marshalling } \\
\text { resources needed to realize that desired future. }\end{array}$ \\
\hline
\end{tabular}

Deployment of strategy is implemented via such mediums as processes, policies, partnerships and practices. These must be well-executed if strategy is to be satisfactorily fulfilled. The proof of satisfactory fulfillment resides in organisation results and impacts so that the organisation must intend inclusion results and impacts, devise a strategy for these intentions, operational the strategy, specify the sorts of results and impacts desired, and measure the level of their attainment.

\subsection{Benefits of Inclusion}

From Biblical times until now, long drumbeats of poetry and prose bear witness to the march of humanity's long history of bending both nature and other men to its often ill-conceived will. In 
contrast, inclusive organisations have emerged that seek to disrupt this rhythm and create cadences composed in collaboration with the people and societies served and impacted by the organisation. This should build and maintain trust and mutual respect, be sensitive to social and environmental conditions, and establish new norms wherein organisations routinely function at the intersection of profitability, social responsibility, and environmental responsibility (Picciotti, 2017).

Benefits of inclusion realised by organisation may include increased consumption and hence increased profitability (Christensen et al., 2015), healthier natural habitats, improved social fabric, increased self-sufficiency and thus elevated human dignity, improved potential for conflict avoidance (Galtung, 2018).

\subsection{Contemporary Case Study: Penalties of Division and Exclusion}

While the virtues of inclusion can be extolled, the penalties of inclusion's obverse side - division and exclusion - are also notable. Still, few organisations understand these penalties and most are surprised when they arise. In late May 2020, the United States was in the early stages of widespread social unrest and protests following the brutal murder of an African American male, George Floyd, by a now former law enforcement officer and three colleagues. These officers are awaiting trial as of this writing. While the murder of George Floyd was a catalyst of unrest, the unrest itself is also motivated by more than 400 years of institutionalised oppression of people of African descent and is emblematic of firmly established and long-practiced systemic oppression of other people groups in America.

Accompanying legitimate protests has been significant illegal activity such as looting and property destruction - presumably by outside agitators seeking either to delegitimise the protests while simultaneously escalating their intensity. Much of the illegal activity perpetrated during the protests has been documented to have been carried out by individuals less interested in protesting than in profiting from the tragedy of some and the commitment to justice of others.

In a glaring example of the cost of division and exclusion to just one small business, a single automobile dealership had 50 new cars stolen, some valued at as much as USD 100,000. More than 10,000 arrests have resulted from ongoing unrest, with use of force against American citizens engaged in peaceful protest urged by the now former U.S. president and exercised in an overt, visceral, and much maligned manner near Lafayette Park, adjacent to the White House. This latter action prompted James Mattis, former United States Marine Corps Four-Star General and former Trump administration United States Secretary of Defense to issue a June 2020 statement denouncing the former President, in part highlighting his proclivity to divide, rather than unite - a proclivity that is figuratively "tearing the nation in two". The full text of General Mattis' statement can be found in Appendix C (Goldberg, 2020).

While this example is an American one, such phenomena are far from unique to the United States. Individuals, organisations and nations routinely view events such as the murder of George Floyd and subsequent protests as one-off events, rather than as outcomes of systemic problems in need of systemic remedies at individual, organisational and national levels. That being said, a growing number of organisations are demonstrating awareness, understanding, resolve and commitment to appropriate action aimed at eradication of systematised division and exclusion. Notable among these organisations are Ben \& Jerry's (a Unilever brand), Nike, Netflix, Twitter, Disney, Facebook and Intel (Ziady, 2020). A description of Ben \& Jerry's reaction to the unrest and underlying causes is provided in Appendix $D$.

Organisations can influence the beliefs and practices of their people and nations. One way of doing so, as has been done by Ben \& Jerry's is to build inclusion into organisational business models and practices. Whether progress is made at national and international levels is yet to be determined, as America and other nations have long histories of dialogue without meaningful change relative to exclusion and division, especially relative to racism (Yancy, 2018). 


\section{Prose and Principles of Circular Economies}

Circular economies were popularised by the landmark work Cradle-to-Cradle: Remaking the Way We Make Things (McDonough and Braungart, 2002). Cradle-to-cradle principles contrast sharply with the cradle-to-the-grave analogy of life wherein we are born, we live, and we die. Cradle-to-cradle instead aims to separate and recirculate the technical or biological nutrients initially used to make a product, doing so at the end of a product's life. Recirculation implies rededication of nutrients to a same or similar use, an altogether new use, or repatriation of nutrients to the source from which they sprang, essentially recirculating those nutrients as many times as possible as a form of resource conservation or preservation. Ideal recirculation would accomplish this ad infinitum, with each cycle yielding progressively improved application of nutrients. Going circular refers to the necessary change from the historic and still prevalent take-make-waste linear economy to a borrow-use-return circular economy. The circular economy is also referred to as the zero-waste or cradle-to-cradle economy. The Ellen Macarthur Foundation (EMF) describes circular economies as ones that rebuild financial, manufactured, human, social, or natural capital, noting that this ensures improved flows of goods and services, citing three primary principles and four building blocks of a circular economy(Table2)(https://www.ellenmacarthurfoundation.org/circulareconomy/concept/schools-of-thought),

Table 2: Circular Economy Principles \& Building Blocks

\begin{tabular}{|c|c|}
\hline Principle & Description \\
\hline 1 & $\begin{array}{l}\text { Preserve natural capital by controlling finite supply stocks and balancing renewable } \\
\text { resource flows. }\end{array}$ \\
\hline 2 & $\begin{array}{l}\text { Optimize resource yields by circulating products, components and materials in use } \\
\text { at the highest utility at all times in both technical and biological cycles. }\end{array}$ \\
\hline 3 & Promote system effectiveness by revealing and designing out negative externalities. \\
\hline $\begin{array}{l}\text { Building } \\
\text { Block }\end{array}$ & Description \\
\hline $\begin{array}{l}\text { Circular } \\
\text { Economy } \\
\text { Design }\end{array}$ & $\begin{array}{l}\text { Enterprises must build core competencies consistent with circular design to advance } \\
\text { material reuse, recycling and cascading. Successful circular design factors include } \\
\text { material selection, standardization, designed-to-last products, design for end-of-life } \\
\text { sorting, separation or reuse of materials, and design for manufacturability } \\
\text { approaches that better enable applications of waste and by-products. }\end{array}$ \\
\hline $\begin{array}{l}\text { New } \\
\text { Business } \\
\text { Models }\end{array}$ & $\begin{array}{l}\text { New and innovative circular business models that enable market leaders and } \\
\text { enterprises with strong capabilities along vertical streams of linear value chains to } \\
\text { drive circularity into the mainstream and influence circular economy innovation are } \\
\text { required. Profitable circular models and initiatives will inspire other actors. }\end{array}$ \\
\hline $\begin{array}{l}\text { Reverse } \\
\text { Cycles }\end{array}$ & $\begin{array}{l}\text { New, additional, and refined skills that aid cascades and return of materials to the } \\
\text { soil or back into the industrial production system are needed. Better collection and } \\
\text { treatment systems that are cost-effective, along with effective segmentation of end- } \\
\text { of-life products, will decrease leakage of materials from the system and support } \\
\text { circular design economics. }\end{array}$ \\
\hline $\begin{array}{l}\text { Enablers \& } \\
\text { Favorable } \\
\text { System } \\
\text { Conditions }\end{array}$ & $\begin{array}{l}\text { Market mechanisms must play a dominant role, with support by policymakers, } \\
\text { educational institutions, and popular opinion leaders if widespread material reuse } \\
\text { and higher resources productivity are to be commonplace. Enablers include rapid } \\
\text { upscaling, environmental standards, collaboration, and rethinking incentives.. }\end{array}$ \\
\hline
\end{tabular}

Source: Ellen MacArthur Foundation

Circular economy pursuit requires elimination of vicious cycles and construction of essential interconnected virtuous ones (Edgeman, 2017; Edgeman et al., 2018), where such cycles are complex chains of actions and their results that reinforce themselves via feedback loops. 
Rick Edgeman, Kunal Yogen Sevak

The Circle Game: Poetry and Sustainable Enterprises

Virtuous cycles perpetuate positive or desirable performance and impacts. Vicious cycles deliver persistently damaging performance and impacts. Perspectives consistent with these circular economy principles and building blocks provided in Table 2 are expressed in the film, Closing the Loop, directed by Graham Sheldon and released by Amazon Video on Earth Day, 22 April 2018. A selection of these perspectives is provided in Table 3.

Table 3. Circular Economy Perspectives

\begin{tabular}{|c|c|}
\hline Person & Perspective \\
\hline $\begin{array}{l}\text { Wayne Visser, Professor of } \\
\text { Integrated Value \& Chair in } \\
\text { Sustainable Transformation, } \\
\text { Antwerp Management School }\end{array}$ & $\begin{array}{l}\text { We need to think about this revolution that we're going through as } \\
\text { a way in which we can make our mark on this earth - a positive } \\
\text { footprint. Do you want to be part of the decline of civilisation or do } \\
\text { you want to be on the side of hope, of reinvention, of recreation, of } \\
\text { the kind of life and the kind of earth that we were really meant to } \\
\text { enjoy? The choice, as always, is yours. Unless we go to Circular it's } \\
\text { game over for the planet; it's game over for society. }\end{array}$ \\
\hline $\begin{array}{l}\text { Rien Otto, Founder and CEO, } \\
\text { Dutch Awareness }\end{array}$ & $\begin{array}{l}\text { If we really don't change our mindset, I think it will be the end of } \\
\text { the world. I think that the circular economy is all about co-creation } \\
\text { working together, bringing all the innovation and knowledge } \\
\text { together in one chain and being responsible. }\end{array}$ \\
\hline $\begin{array}{l}\text { Ian Ellison, Sr. Associate, } \\
\text { Cambridge Institute for } \\
\text { Sustainability Leadership }\end{array}$ & $\begin{array}{l}\text { If you're getting very significant reductions in pollution and waste, } \\
\text { if you're using waste material as your fundamental building blocks, } \\
\text { then you ought to be able to reduce costs and also improve output } \\
\text { from the same resource base. }\end{array}$ \\
\hline $\begin{array}{l}\text { Ramon Arattia, Sustainability } \\
\text { Director, Interface }\end{array}$ & $\begin{array}{l}\text { There are many opportunities in the waste from other industries. If } \\
\text { other industries are not clever enough to recycle their own waste, } \\
\text { we will look at what is the potential waste which is interesting for } \\
\text { us. }\end{array}$ \\
\hline $\begin{array}{l}\text { Lesibana Ledwaba, Executive } \\
\text { Director for Operational } \\
\text { Transformation and Strategy, } \\
\text { Barloworld Equipment }\end{array}$ & $\begin{array}{l}\text { Through remanufacturing we are able to reduce the cost of doing } \\
\text { business, because we are able to give the customers components } \\
\text { at a fraction of what it would cost to get a new one. }\end{array}$ \\
\hline $\begin{array}{l}\text { Stacey Davidson, Executive } \\
\text { Director, REDISA }\end{array}$ & $\begin{array}{l}\text { We do know that pushing for the circular economy, we are able to } \\
\text { change lives. We can never underestimate the power of the social } \\
\text { impact that you're achieving through the circular economy. }\end{array}$ \\
\hline $\begin{array}{l}\text { Sir John Elkington, Executive } \\
\text { Chairman and Co-Founder, } \\
\text { Volans Ventures }\end{array}$ & $\begin{array}{l}\text { Part of our problem in moving towards circularity is most people } \\
\text { neither see the importance of it nor exactly know how to do it. If } \\
\text { we continue with the linear economy, we are, to use a technical } \\
\text { term, totally screwed. }\end{array}$ \\
\hline
\end{tabular}

Source: Closing the Loop, Amazon Video, 2018

\section{Circular Economies, Inclusion and Excellence Models: Next Steps}

Enterprise performance models - often referred to as excellence models - rose to prominence in the 1980 s and 1990 s and have involved substantially since. Such models examine enterprise leadership, financial performance, operational performance, employee performance, supplier performance and other performance domains, as well as the organisation's strategy and means by which its performance is attained.

Until recently, enterprise excellence models have minimised measurement of social and environmental performance, leaving this to, e.g., British Standard 7750, the ISO 14000 series 
of Environmental Management Standards, Global Reporting Initiative, United Nations Global Compact, and the ISO 26000 Social Responsibility Guidance Standards that incorporate the triple bottom line dimensions of environmental responsibility, social equity and, to a lesser extent, economic or financial performance (Deleryd \& Fundin, 2020; Edgeman and Eskildsen, 2014; Elkington and Trisoglio, 1996).

Integrated modelling that weds excellence models with social and environmental sustainability and justice considerations (nee: inclusion) seeks the best compromise-solution, at the level the model is applied (usually enterprise or division) and such a model may be referred to as a sustainable enterprise excellence model (SEEM) (Edgeman and Eskildsen, 2014). Such models are highly adaptable and may be customised by weighting their key elements according to a blend of stakeholder priorities or standards, with common stakeholders including the enterprise, community (society), or governmental entities:

Sustainable enterprise excellence results from ongoing balance among the competing and complementary interests of key stakeholder segments. In addition to more commonly noted stakeholder segments such as customers, shareholders, and policymakers, SEE deeply integrates society as an explicit stakeholder and the natural environment as an implicit one. Attainment of such balance increases enterprise likelihood of creating superior and sustainable competitive positioning and long-term enterprise success. This is accomplished through an integrated approach to organisational design and function emphasising innovation, operational, customer-related, human capital, financial, marketplace, societal, and environmental performance.

SEE supports enterprise responsibility and relevancy but does not ensure enterprise longevity. Advancement of enterprise longevity, resilience and robustness are added to the portfolio of expectations of what a SEEM must promote. Successful management for sustainable excellence (Edgeman \& Williams, 2013) delivers an enterprise that is:

- Sustainable to the extent it creates and maintains economic, ecological, and social value for itself, its stakeholders, society at large, and policy-makers;

- Resilient to the extent it possesses the capacity to self-renew through innovation by adapting its responses to negative shocks and challenges over time;

- Robust to the degree it is highly resistant or immune to a critical subset of shocks and challenges;

- Excellent when its governance, leadership and strategy as deployed through people, processes, partnerships, and policies deliver sustained superior performance and impact in enterprise-critical areas such as enterprise human ecology, innovation, financial, social, ecological, enterprise intelligence gathering, analytics, and supply chain management.

Inclusion and circularity must be incorporated in any new generation SEEM. This should occur with respect to core values, guiding principles, and purpose that drive strategy, execution of which will deliver performance and impacts that reflect their inclusion. Performance and impacts assessed are will be ones relative to the social equity and environmentally responsible portions of the triple bottom line since these are both inward-and-outward facing, whereas financial performance is primarily inward-facing.

Generic SEE strategy will be triple top line in nature in that it incorporates social equity, environmental sensitivity, and financial wisdom (Smith, 2004). Conscious integration of inclusion and circularity in an organisation's SEEM is more likely to represent intentional elevation of these elements, as opposed to addition of things previously absent from the model.

Strategy must be executed via such means as resource dedication, processes, partnerships, practices and policies. The purpose of these is translation of strategy into socially responsible, 
ecologically neutral or positive, and sufficient financial performance and impacts, as well as any other types of performance and impacts targeted by the organisation (Edgeman, Eskildsen and Neely, 2015).

Enterprise excellence models are most often used for organisational self-assessment, where relevant enterprise strategies, actions and results are appraised relative to specific model criteria believed to be strongly correlated with organizational success / failure. Enterprise assessment is intended to provide actionable insight into the recent fruits and failures of enterprise strategies, actions and performance and to inform future strategy.

How can SEE models be adapted to better harmonise with Circular Economy principles? A lean list of harmonisation principles derives from understanding that circular-economy business practices emphasise reuse and extension of product and service life through repair, remanufacture, upgrades and retrofits where possible, and transformation of old goods into asnew resources for future goods by recycling of technological and biological materials (Stahel, 2016).

Additional enterprise ideas with added objectives must also be incorporated. Among these are

- Innovate, Design and Redesign for the Future: create new ideas, products, services, institutions and relationships that offer promising approaches to vital social and environmental challenges. Innovative designs and redesigns should encourage ease of maintenance, redesign, and recycling of technological or biological components (Linder and Williander, 2017).

- Incorporate Digital Technology (DT): wherever possible incorporate DT as proxies for tangible products or transportation and effective monitoring and moderation of resource and energy use.

- An Extended View of Stakeholders: the circular economy has many stakeholders with many concerns and requirements. The stakeholders represented in Figure 2 greatly exceed in both number and scope the number those commonly included among stakeholder lists

- Change Minds and Habits: the principle of sufficiency must be understood and practiced within the enterprise and by society. Expression of sufficiency is found in the practice of lagom, the Swedish notion of "just enough" underlying a balanced, happy life - a notion consistent with many non-western national cultures such as in Bhutan, Indonesia, and Thailand (Fischer et. al., 2012).

- Currencies of the Future: embed appreciation in guiding principles, strategy, deployment, and performance and impacts that dollars, euros, pounds and yen are surrogates for true currencies such as water, food, warmth, clothing, energy, transportation, safety, security and shelter.

- Listen, Learn and Do Better: excellence models incorporate the voices of stakeholders, including those cited in Figure 2, together with customers, investors, and others. In addition to common means of listening such as surveys and focus groups, more in-depth or technologically enabled methods such as ethnographic research (living among and observing intended end-users in the actual use environment), social listening, advanced analytics, complaint feedback, and market research are among enabling means of listening, learning, and doing better that should be incorporated to develop better understanding of needs and expectations and delivery of better solutions. 
Rick Edgeman, Kunal Yogen Sevak

The Circle Game: Poetry and Sustainable Enterprises

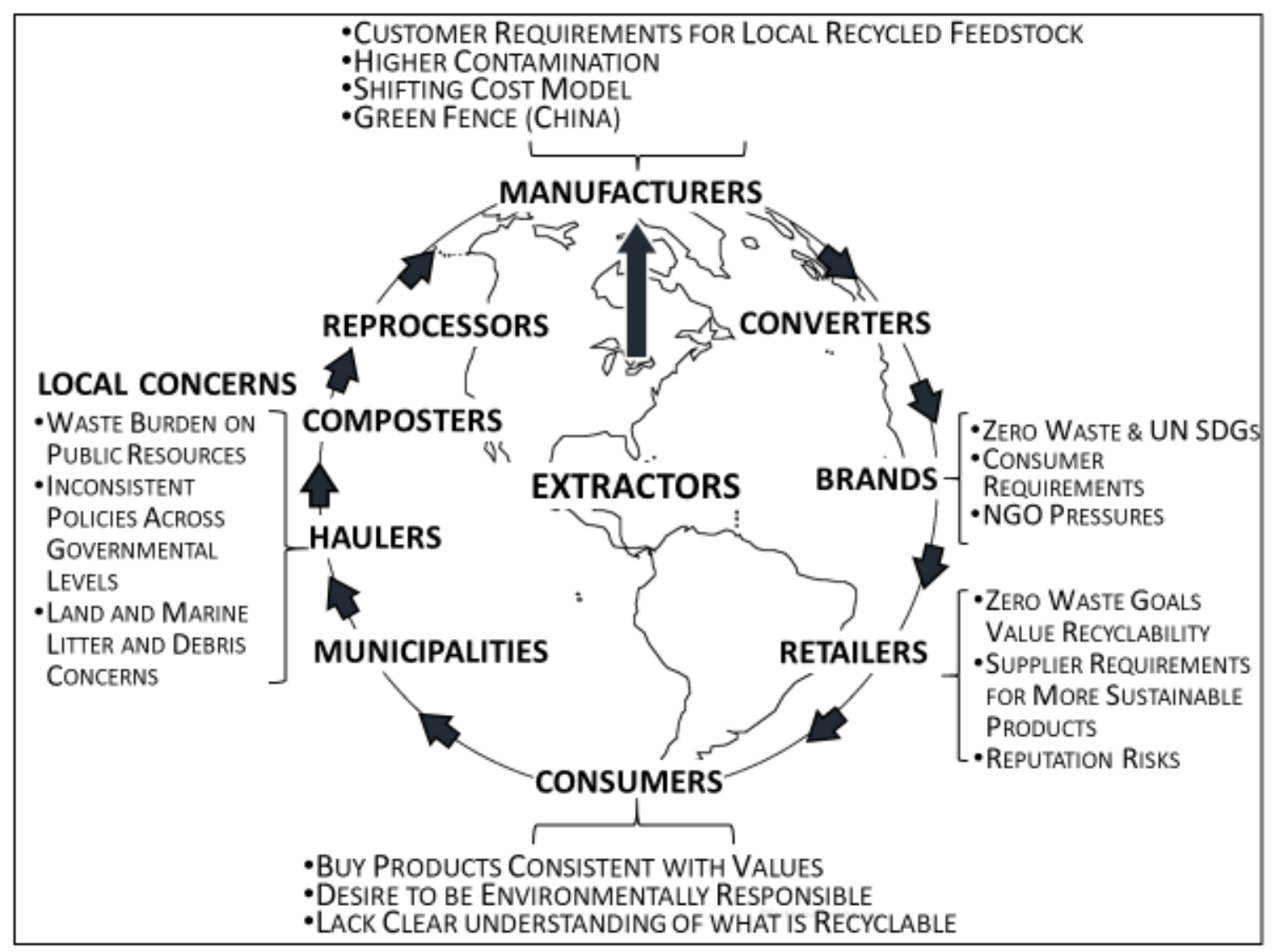

Figure 2: Selected Circular Economy Stakeholders and Issues.

\section{Summary and Conclusions}

Integration of circular economy principles with SEE models can be expressed in many ways and at differing levels of detail. The resulting model can be referred to as a Circular, Inclusive and Sustainable Enterprise Excellence Model (CISEEM). As with SEEMs, CISEEMs are most fruitful when used for enterprise self-assessment purposes. The reason for this is that rigorous application of a CISEEM leads to continuous enterprise improvement relative to model elements and supporting criteria. Because CISEEMs explicitly promote circularity and sustainability, they will promote social and environmental progress. A relatively generic CISEEM is provided in Figure 3.

Guiding principles, core values and purpose are likely to be a blend of widely-used ones, such as those associated with the United Nations Global Compact or United Nations Sustainable Development Goals, and other more specific to the organisation. Examples of the latter include lead with humility, mutual respect, scientific and critical thinking, creative conflict, or ones devoted to innovation. Formation of effective strategy ordinarily requires deep knowledge of and insight into markets, technologies, communities and competitors so that one key strategy element may be related to acquisition, processing and development of insight into these. Cultivating such knowledge relative to marginalised communities is challenging and likely to require more expensive and more time-consuming acquisition efforts, such as ethnographic research that requires direct experience in those communities, with and among the people (Shagrir, 2017). 
Rick Edgeman, Kunal Yogen Sevak

The Circle Game: Poetry and Sustainable Enterprises

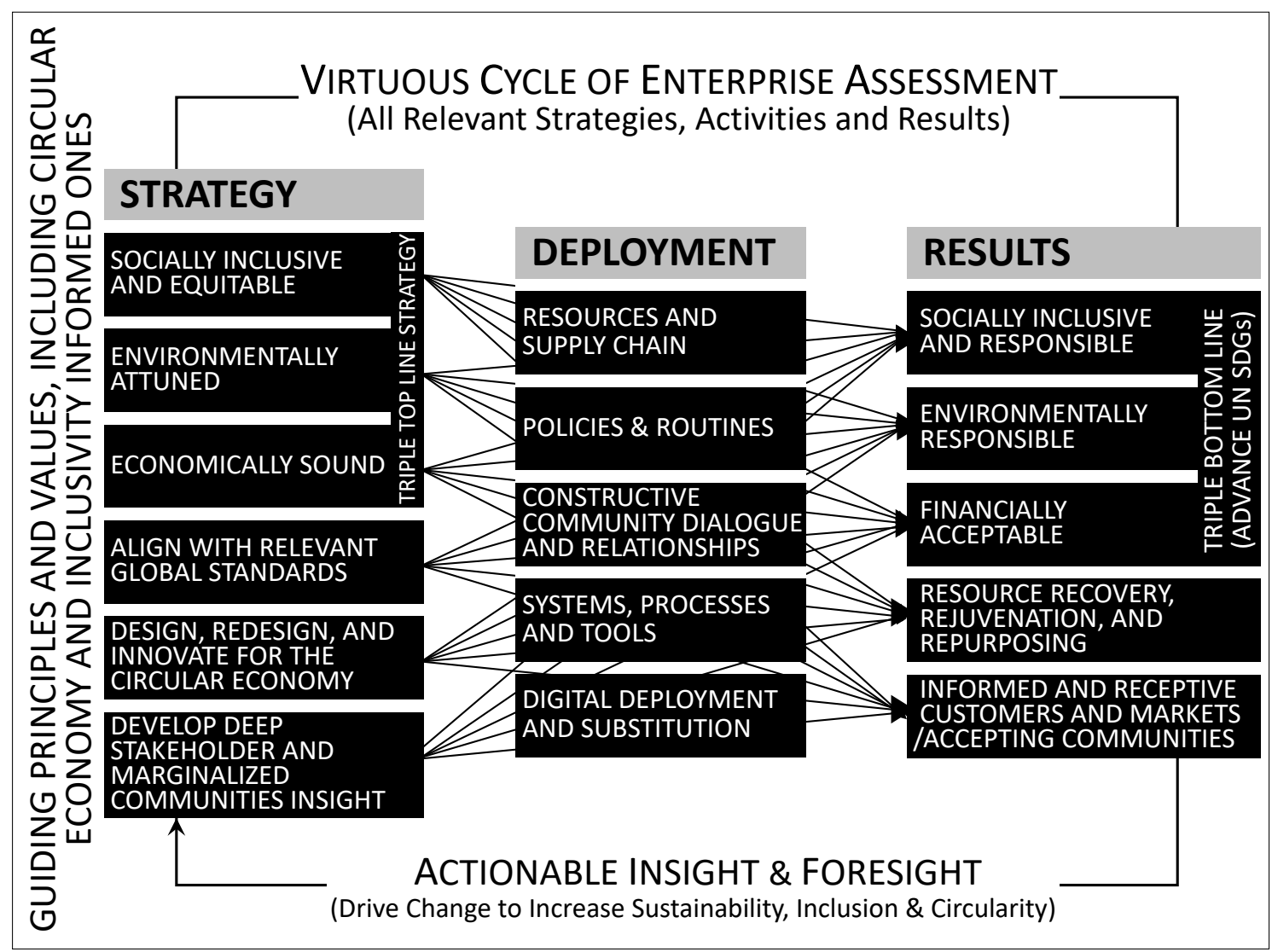

Figure 3. Generic Circular and Sustainable Enterprise Excellence Model.

Until such deep understanding is developed, an organisation's strategy, execution and outcomes will be less than would have otherwise been possible. Regardless, greater inclusivity and progress toward circularity can be attained by being mindful of and committed to these, even if our knowledge is partially lacking. Commitment is more than a mindset however, it is a commitment of passion, resources, and to relevant action. Coupling these with a customised Circular, Inclusive and Sustainable Enterprise Excellence Model can elevate an organisation's contributions toward inclusion and circularity, improving the plight of the marginalised and the planet alike in doing so.

\section{References}

- Ben \& Jerry's (2020, June). We must dismantle white supremacy: Silence is not an option. Ben \& Jerry's website: https://www.benjerry.com/about-us/media-center/dismantle-whitesupremacy.

- Broadstock, D.C.; Managi, S.; Matousek, R.; Tzeremes, N.G. (2019) Does doing "good" always translate into doing "well"? An eco-efficiency perspective. Business Strategy and the Environment, 28(6). Crossref

- Christensen, L.J.; Siesen, E.; Balasubramanian, S. (2015) Consumer behavior change at the base of the pyramid: Bridging the gap between for-profit and social responsibility strategies. Strategic Management Journal, 36(2). Crossref

- Davidson, J.O. (2015) Modern Slavery: The Margins of Freedom. Palgrave Macmillan: London, UK. DOI: $10.1057 / 9781137297297$ Crossref

- Deleryd, M.; Fundin, A. (2020) Towards societal satisfaction in a fifth generation of quality the sustainability model. Total Quality Management \& Business Excellence, Published online: 29 December 2020. Crossref

- Edgeman, R. (2017) Routinizing peak performance and impacts via virtuous cycles. Measuring Business Excellence, Volume 21, Number 3. Crossref 
- Edgeman, R. (2018) Excellence models as complex management systems: An examination of the Shingo operational excellence model. Business Process Management Journal, 24(6). Crossref

- Edgeman, R. (2019a) Performance management and enterprise excellence through SBMs. In: Sustainable Business Model Innovation, Aagaard, A. (Ed.) Palgrave Macmillan: London, UK, 317-359. DOI: 10.1007/978-3-319-93275-0_11 Crossref

- Edgeman, R. (2019b) Complex Management Systems and the Shingo Model: Foundations of Operational Excellence and Supporting Tools; Productivity Press: New York, NY, USA. Crossref

- Edgeman, R.; Eskildsen, J. (2014) Modeling and assessing sustainable enterprise excellence. Business Strategy and the Environment, 23(3). Crossref

- Edgeman, R.; Eskildsen, J.; Neely, A. (2015) Translating triple top-line strategy into triple bottom line performance. Measuring Business Excellence, 19(1). Crossref

- Edgeman, R.; Hammond, S.; Keller, C.; McGraw, J. (2018) Virtuous cycles: Organisational dynamics of innovation \& excellence. Total Quality Management \& Business Excellence, Published online: 16 May 2018. Crossref

- Edgeman, R.; Williams, J.A. (2014) Enterprise self-assessment analytics for sustainability, resilience and robustness. The TQM Journal, 26(4). https://www.emerald.com/insight/content/doi/10.1108/TQM-01-2014-0012/ Crossref

- Elkington, J.; Trisoglio, A. (1996) Developing realistic scenarios for the environment: Lessons from Brent Spar, Long Range Planning, 29(6). Crossref

- Fischer, J.; Dyball, R.; Fazey, I.; Gross, C.; Dovers, S.; Erlich, P.; Brulle, R.; Christensen, C.; Borden, R. (2012) Human behavior and sustainability. Frontiers in Ecology and Environment, 10(3). Crossref

- Galtung, J. (2019) Peace institutions: Gandhism, conflict solution, lifting the bottom up. In: The Palgrave Handbook of Global Approaches to Peace, Kulnazarova, A.; Popovski, V. (Eds.) Palgrave Macmillan, Cham, Switzerland. Crossref

- Goldberg, J. (2020) In union there is strength. The Atlantic. Published online: 3 June 2020. https://www.theatlantic.com/politics/archive/2020/06/james-mattis-denounces-trumpprotests-militarization/612640/

- Hahn, R. (2012) Inclusive business, human rights and the dignity of the poor: A glance beyond economic impacts of adapted business model. Business Ethics: A European Review, 21(1). Crossref

- Hiller, J.S. (2013) The benefit corporation and corporate social responsibility. Journal of Business Ethics, 118. DOI 10.1007/s10551-012-1580-3. Crossref

- Joncourt, S.; Gebauer, H.; Reynoso, J.; Cabrera, K.; Valdes, A.; Greve, K. (2019) Extending the base-of-the-pyramid concept. Service Science, 11(3). Crossref

- Kipling, R. (1920) The Finest Story in the World and Other Stories. Robert K. Haas, Inc.: New York, USA.

- Kourula, A.; Pisani, N; Kolk, A. (2017) Corporate sustainability and inclusive development: Highlights from international business and management research. Current Opinion in Environmental Sustainability, 24(2). Crossref

- Linder, M.; Williander, M. (2017) Circular business model innovation: Inherent uncertainties. Business Strategy and the Environment, 26(2). Crossref

- McDonough, W.; Braungart, M. (2002) Cradle to Cradle: Remaking the Way We Make Things. New York NY: North Point Press.

- McIntyre-Mills, J. (2003) Critical Systemic Praxis for Social and Environmental Justice: Participatory Policy Design and Governance for a Global Age. Kluwer Academic / Plenum Publishers: New York, USA. Crossref

- McIntyre-Mills, J. (2018) Recognizing our hybridity and interconnectedness: Implications for social and environmental justice. Current Sociology Review, 66(6), 886-910. DOI: $10.1177 / 0011392117715898 \quad \underline{\text { Crossref }}$

- Michelini, L.; Fiorentino, D. (2012) New business models for creating shared value. Social Responsibility Journal, 8(4). Crossref

- Mitchell, J. (2019) The Complete Poems and Lyrics. Chatto \& Windus, London, UK.

- Nason, R.W. (2008) Structuring the global marketplace: The impact of the United Nations Global Compact. Journal of Macromarketing, 28(4). Crossref

- Olsson, P.; Galaz, V. (2012) Social-ecological innovation and transformation. In: Social Innovation; Nicholls, A., Murdock, A., Eds. Macmillan: London, UK. Crossref

- Pfitzer, M.; Bockstette, V.; Stamp, M. (2013) Innovating for shared value. Harvard Business Review, 91(9).

- Picciotti, A. (2017) Towards sustainability: The innovation paths of social enterprise. Annals of Public and Cooperative Economics, 88(2). Crossref 
- Porter, M.E.; Kramer, M.R. (2019) Creating shared value. In: Managing Sustainable Business; Lenssen, G.; Smith, N. (Eds.) Springer, Dordrecht, The Netherlands. Crossref

- Reiser, D.B. (2011) Benefit corporations - a sustainable form of Organisation. Wake Forest Law Review, 46.

- Sabadoz, C. (2011) Between profit-seeking and prosociality: Corporate social responsibility as Derridean supplement. Journal of Business Ethics, 104. DOI: 10.1007/s10551-011-08901. Crossref

- Sabeti, H. (2011) The for-benefit enterprise. Harvard Business Review, Volume 89(11).

- Schwartz, S.H. (2007) Universalism values and the inclusiveness of our moral universe. Journal of Cross-Cultural Psychology, 38(6). Crossref

- Sethi, S.P.; Schepers, D.H. (2014) United Nations Global Compact: The promiseperformance gap. Journal of Business Ethics, 122(2). Crossref

- Shagrir, L. (2017) Journey to Ethnographic Research. New York, NY: Springer International Publishing. Crossref

- Smith, L.R. (2004) The triple top-line. Quality Progress, 37(2), 23-27.

- Stahel, W.R. (2016) The circular economy. Nature, 531(7575). DOI: 10.1038/531435a. Crossref

- Veleva, V.; Bodkin, G.; Todorova, S. (2017) The need for better measurement and employee engagement to advance a circular economy: Lessons from Biogen's 'zero waste' journey. Journal of Cleaner Production, 154(15). Crossref

- Yancy, G. (2018) Backlash: What Happens When We Talk Honestly about Racism in America? London, UK: Rowman \& Littlefield Publishing.

- Ziady, H. (2020, June) Why Ben \& Jerry's statement on white supremacy is so powerful. https://www.cnn.com/2020/06/03/business/ben--jerrys-george-floyd/index.html.

\section{Appendix A: Lyrics of "The Circle Game" y Joni Mitchell}

Yesterday a child came out to wonder, caught a dragonfly inside a jar.

Fearful when the sky was full of thunder, and tearful at the falling of a star.

Then the child moved ten times 'round the seasons,

skated over ten clear frozen streams.

Words like 'when you're older' must appease him, and promises of someday make his dreams.

REFRAIN:

And the seasons, they go 'round and 'round, and the painted ponies go up and down.

We're captive on the carousel of time.

We can't return, we can only look behind from where we came, And go 'round and 'round and 'round in the circle game.

Sixteen springs and sixteen summers gone now, cartwheels turn to car wheels through the town.

And they tell him, 'take your time, it won't be long now, till you drag your feet to slow the circles down.'

\section{REPEAT REFRAIN}

So, the years spin by and now the boy is twenty, though his dreams have lost some grandeur coming true. There'll be new dreams, maybe better dreams and plenty, before the last revolving year is through. 


\section{Appendix B: "The Song of The Galley Slave" By Rudyard Kipling}

We pulled for you when the wind was against us and sails were low. Will you never let us go? We ate bread and onions when you took towns or ran aboard quickly when you were beaten back by the foe.

The Captains walked up and down the deck in fair weather singing songs, but we were below. We fainted with our chins on the oars and you did not see that we were idle, for we swing to and fro. Will you never let us go?

The salt made the oar-handles like shark-skin; our knees were cut to the bone with salt-cracks; our hair was stuck to our foreheads, and our lips were cut to the gums, and you whipped us because we could not row.

Will you never let us go?

But, in a little time, we shall run out of the portholes as the water runs along the oar-blade, and though you tell the others to row after us you will never catch us till you catch the oar-thresh and tie up the winds in the belly of the sail. Aho!

Will you never let us go?

\section{Appendix C: General James Mattis' Statement - In Union There Is Strength}

I have watched this week's unfolding events, angry and appalled. The words "Equal Justice Under Law" are carved in the pediment of the United States Supreme Court. This is precisely what protesters are rightly demanding. It is a wholesome and unifying demand-one that all of us should be able to get behind. We must not be distracted by a small number of lawbreakers. The protests are defined by tens of thousands of people of conscience who are insisting that we live up to our values-our values as people and our values as a nation.

When I joined the military, some 50 years ago, I swore an oath to support and defend the Constitution. Never did I dream that troops taking that same oath would be ordered under any circumstance to violate the Constitutional rights of their fellow citizens-much less to provide a bizarre photo op for the elected commander-in-chief, with military leadership standing alongside.

We must reject any thinking of our cities as a "battlespace" that our uniformed military is called upon to "dominate." At home, we should use our military only when requested to do so, on very rare occasions, by state governors. Militarizing our response, as we witnessed in Washington, D.C., sets up a conflict-a false conflict-between the military and civilian society. It erodes the moral ground that ensures a trusted bond between men and women in uniform and the society they are sworn to protect, and of which they themselves are a part. Keeping public order rests with civilian state and local leaders who best understand their communities and are answerable to them.

James Madison wrote in Federalist 14 that "America united with a handful of troops, or without a single soldier, exhibits a more forbidding posture to foreign ambition than America disunited, with a hundred thousand veterans ready for combat." We do not need to militarize our response to protests. We need to unite around a common purpose. And it starts by guaranteeing that all of us are equal before the law.

Instructions given by the military departments to our troops before the Normandy invasion reminded soldiers that "The Nazi slogan for destroying us...was 'Divide and Conquer.' Our American answer is 'In Union there is Strength."' We must summon that unity to surmount this crisis-confident that we are better than our politics. 
Donald Trump is the first president in my lifetime who does not try to unite the American peopledoes not even pretend to try. Instead, he tries to divide us. We are witnessing the consequences of three years of this deliberate effort. We are witnessing the consequences of three years without mature leadership. We can unite without him, drawing on the strengths inherent in our civil society. This will not be easy, as the past few days have shown, but we owe it to our fellow citizens; to past generations that bled to defend our promise; and to our children.

We can come through this trying time stronger, and with a renewed sense of purpose and respect for one another. The pandemic has shown us that it is not only our troops who are willing to offer the ultimate sacrifice for the safety of the community. Americans in hospitals, grocery stores, post offices, and elsewhere have put their lives on the line in order to serve their fellow citizens and their country. We know that we are better than the abuse of executive authority that we witnessed in Lafayette Park. We must reject and hold accountable those in office who would make a mockery of our Constitution. At the same time, we must remember Lincoln's "better angels," and listen to them, as we work to unite.

Only by adopting a new path-which means, in truth, returning to the original path of our founding ideals-will we again be a country admired and respected at home and abroad.

\section{Appendix D: White Supremacy Must Be Dismantled: Silence Is Not an Option}

All of us at Ben \& Jerry's are outraged about the murder of another Black person by Minneapolis police officers last week and the continued violent response by police against protestors. We have to speak out. We have to stand together with the victims of murder, marginalization, and repression because of their skin colour, and with those who seek justice through protests across our country. We have to say his name: George Floyd.

George Floyd was a son, a brother, a father, and a friend. The police officer who put his knee on George Floyd's neck and the police officers who stood by and watched didn't just murder George Floyd, they stole him. They stole him from his family and his friends, his church and his community, and from his own future.

The murder of George Floyd was the result of inhumane police brutality that is perpetuated by a culture of white supremacy. What happened to George Floyd was not the result of a bad apple; it was the predictable consequence of a racist and prejudiced system and culture that has treated Black bodies as the enemy from the beginning. What happened to George Floyd in Minneapolis is the fruit borne of toxic seeds planted on the shores of our country in Jamestown in 1619, when the first enslaved men and women arrived on this continent. Floyd is the latest in a long list of names that stretches back to that time and that shore. Some of those names we know - Ahmaud Arbery, Breonna Taylor, Oscar Grant, Eric Garner, Trayvon Martin, Michael Brown, Emmett Till, Martin Luther King, Jr. - most we don't.

The officers who murdered George Floyd, who stole him from those who loved him, must be brought to justice. At the same time, we must embark on the more complicated work of delivering justice for all the victims of state sponsored violence and racism.

Four years ago, we publicly stated our support for the Black Lives Matter movement. Today, we want to be even more clear about the urgent need to take concrete steps to dismantle white supremacy in all its forms. To do that, we are calling for four things:

First, we call upon President Trump, elected officials, and political parties to commit our nation to a formal process of healing and reconciliation. Instead of calling for the use of aggressive tactics on protestors, the President must take the first step by disavowing white supremacists and nationalist 
Rick Edgeman, Kunal Yogen Sevak

The Circle Game: Poetry and Sustainable Enterprises

groups that overtly support him, and by not using his Twitter feed to promote and normalize their ideas and agendas. The world is watching America's response.

Second, we call upon the Congress to pass $\underline{\text { H.R. } 40}$, legislation that would create a commission to study the effects of slavery and discrimination from 1619 to the present and recommend appropriate remedies. We cannot move forward together as a nation until we begin to grapple with the sins of our past. Slavery, Jim Crow, and segregation were systems of legalized and monetized white supremacy for which generations of Black and Brown people paid an immeasurable price. That cost must be acknowledged and the privilege that accrued to some at the expense of others must be reckoned with and redressed.

Third, we support Floyd's family's call to create a national task force that would draft bipartisan legislation aimed at ending racial violence and increasing police accountability. We can't continue to fund a criminal justice system that perpetuates mass incarceration while at the same time threatens the lives of a whole segment of the population.

And finally, we call on the Department of Justice to reinvigorate its Civil Rights Division as a staunch defender of the rights of Black and Brown people. The DOJ must also reinstate policies rolled back under the Trump Administration, such as consent decrees to curb police abuses.

Unless and until white America is willing to collectively acknowledge its privilege, take responsibility for its past and the impact it has on the present, and commit to creating a future steeped in justice, the list of names that George Floyd has been added to will never end. We have to use this moment to accelerate our nation's long journey towards justice and a more perfect union. 